\title{
Seasonal Changes in Productive and Reproductive Performance in Holstein Dairy Cows Synchronized for Estrus with the Ovsynch Protocol Under Subtropical Conditions
}

\author{
M. M. Shabaan ${ }^{1}$, A. M. A. $\operatorname{Rashad}^{1}$, A. E. Mahdy $^{1}$, S. Z. El-Zarkouny ${ }^{1,2^{*}}$ and G. A. Hassan ${ }^{1}$ \\ ${ }^{1}$ Department of Animal and Fish Production, Faculty of Agriculture, Alexandria University, \\ Alexandria, Egypt, ${ }^{2}$ Department of Arid Land Agriculture, Faculty of Meteorology, Environment \\ and Arid Land Agriculture King, Abdulaziz University Jeddah, Saudi Arabia
}

\author{
selzarkouny@kau.edu.sa
}

\begin{abstract}
This study aimed to evaluate the effects of heat stress on productive and reproductive performances in Holstein dairy cows during summer compared to winter seasons. During each seasons, temperaturehumidity index (THI), rectal temperature, and respiration rate were recorded for 105 days. Daily milk yield $(\mathrm{Kg} /$ day) was recorded for 5 consecutive months each season. Serum cholesterol, glucose, urea and progesterone $(\mathrm{P} 4)$ concentrations were determined around the times of inseminations. Conception rate to first insemination (CR/AI), overall pregnancy rate, number of services per conception (NSPC) and number of days open (DO) were determined each season. Values of THI, rectal temperatures and respiration rate were greater in summer than winter. Daily milk yield was greater $(\mathrm{P}<0.05)$ in winter months compared to summer. Serum glucose and urea concentrations were greater in summer than winter during the dry period and at the times of $\mathrm{GnRH}$ and PGF injections. However, cholesterol was greater in winter during GnRH and PGF injection times. Serum P4 concentrations were not affected by GnRH treatment in summer, whereas GnRH injection increased P4 concentration during winter season. More winter cows conceived to first AI and required less number of services per conception and had fewer days open compared to summer cows.
\end{abstract}

Keywords: season, heat stress, milk, cow, fertility.

\section{Introduction}

Dairy cows' production and welfare is affected by various factors due to complex interactions between the animal and the environment with its different factors. When the scenarios of global warming are considered, heat stress on high-yielding dairy cows is an increasing concern by milk producers (Gauly, et al., 2013). Under subtropical and tropical climatic conditions, several studies demonstrated the effects of environmental factors (temperature, relative humidity, solar radiation and wind speed) on the productivity of beef and dairy cattle (West, 2003; Berman, 2005; Rhoads et al., 2009). These studies have linked heat stress with decreases in productivity, such as decreasing milk yield, and deteriorated reproductive performance.

The temperature-humidity index (THI) is a commonly used indicator of thermal 
conditions and the degree of heat stress as it incorporates the effects of ambient temperature as well as relative humidity (Yousef, 1987; Hubbard et al., 1999). The relationship between environmental temperature and rectal temperature has been extensively investigated. In Florida, temperatures of $29.7^{\circ} \mathrm{C}$ and $31.4^{\circ} \mathrm{C}$ have been linked to average rectal temperatures of $39^{\circ} \mathrm{C}$ (mild hyperthermia) and $39.5^{\circ} \mathrm{C}$ (hyperthermia), respectively (Dikmen and Hansen, 2009). Rectal temperatures greater than $39^{\circ} \mathrm{C}$ reflect an extent of heat stress that will affect milk production and fertility (Hansen and Arechiga, 1999; West, 2003; Kadokawa et al., 2012). A THI value below 68 units generally does not cause safety problems for healthy animals; under mild discomfort and discomfort conditions $(68 \leq \mathrm{THI} \leq 74)$ heat stress begins to first cause problems; and for a THI above 75 units animals can show noticeable decrease in performance (Bouraoui et al., 2002; Hahn et al., 2003).

According to Rhoads et al. (2009), the milk yield is lower in heat-stressed cows than in cows that are kept in a thermoneutral environment. In Germany, Brügemann et al. (2012) reported 0.08 to $0.26 \mathrm{~kg}$ decline in milk yield for each unit increase in THI unit, depending on the region. Declining productive and reproductive performance of livestock in tropical and subtropical areas is a well-known phenomenon that limits high production dairy cattle breeding (Gauly et al., 2013; Kadzere et al., 2002). As reported by Berman (2005), a shift in the daily milk yield from 35 to $45 \mathrm{~kg} / \mathrm{d}$ leads to a higher sensitivity to thermal stress and reduces the threshold temperature for intermediate heat stress by $5^{\circ} \mathrm{C}$. Under subtropical and tropical climatic conditions, several studies demonstrated the effects of environmental factors (temperature, relative humidity, solar radiation, and wind speed) on the productivity of beef and dairy cattle (West, 2003; Berman, 2005; Rhoads et al., 2009). These studies associated heat stress with decreases in productivity, such as decreasing milk yield, and reproductive performance.

Effect of heat stress on plasma progesterone concentration is more controversial. Some studies (Hahn et al., 2003) found that heat stress had no effect on the plasma progesterone concentrations but that luteolysis was delayed. The changes in blood constituents can reflect the physiological condition as well as nutritional and health status of cows. Acclimation to thermal stress also imposes physiological and metabolic adjustments associated with reduction of performance (Ispierto et al., 2007). Collier et al. (2006) and Kadokawa et al. (2012) detected a decrease in plasma glucose level for dairy cows in winter.

The objectives of this study were to evaluate the effects of heat stress (summer vs. winter) on rectal temperature, respiration rate, reproductive performance and serum composition (glucose, cholesterol and urea) of Holstein dairy cows synchronized with the Ovsynch protocol under subtropical conditions.

\section{Materials and Methods Animals and their management}

The study was conducted on 194 lactating Holstein dairy cows with an average daily milk yield of $25 \mathrm{~kg}$ per cow in Egypt and spanned 2 seasons (summer, $\mathrm{n}=102$ and winter, $n=92$ ) to evaluate the effects of season on dairy cows' production and reproduction and serum constituents. Cows were housed in open barns with shades and machine-milked thrice daily. Cows were fed on green artichoke ( $7 \%$ of BW) from January to April, artichoke silage $(3.5 \%$ of $\mathrm{BW})$ from May to June, chopped green corn ( $4 \%$ of BW) from July to August, and corn silage ( $2 \%$ of $\mathrm{BW})$ and Berseem (5\% of BW) from September to December. A concentrate mixure $(16 \%$ crude protein) consisting of ground yellow corn, soybean meal, wheat bran, cottonseed cake, molasses, rumen-protected fat $(5 \%)$, and minerals (Premix) according to NRC (2007) 
recommendations for lactating dairy cows. Cows had free access to fresh water.

\section{Estrous synchronization and blood samples collection:}

All cows were synchronized for estrus by the ovulation synchronization (Ovsynch) protocol starting 45 days after calving. The Ovsynch treatment consisted of $2 \mathrm{GnRH}$ injections of $8 \mu \mathrm{g}$ Buserelin (Receptal, Intervet International) $9 \mathrm{~d}$ apart plus 1 injection of 500 $\mu \mathrm{g} \quad \mathrm{PGF}_{2 \alpha}$ analogue (Estrumate, ScheringPlough Animal Health) given $48 \mathrm{~h}$ before the second injection of GnRH. Cows received a timed AI using frozen-thawed semen 16 to 20 $h$ after the second injection of GnRH. The first $\mathrm{GnRH}$ injection was administered randomly without regard to stage of the estrous cycle or anovulation. Blood samples were collected via coccygeal venipuncture from all cows at 3 times: dry period, on day 0 ( $\mathrm{GnRH}$ injection) and day $7\left(\mathrm{PGF}_{2 \alpha}\right.$ injection). Blood samples were stored at $4^{\circ} \mathrm{C}$ until serum was harvested after centrifugation. Sera samples were stored at $-20^{\circ} \mathrm{C}$ until assayed.

\section{Biochemical Analysis of Serum Metabolites and Hormones}

Serum biochemical constituents (urea, glucose, cholesterol) were determined colorimetrically using visible light spectrophotometer (Pharmacia, LKB Biochrom, England). All assays were carried out using commercial kits according the manufacturers' guidelines.

Enzyme immunosorbent assay (ELISA) was used for measurement of serum progesterone. Kits (Calbiotech Inc., USA) were used for measuring progesterone concentrations. Lower limit of detection of progesterone was $0.3 \mathrm{ng} / \mathrm{mL}$. Intra- and interassay CV were 7.1 and $2.4 \%$, respectively.

\section{Data collected}

The THI is calculated from the wet and dry bulb air temperatures for a particular day according to the following equation:

$$
\mathrm{THI}=0.72(\mathrm{~W}+\mathrm{D})+40.6
$$

where $\mathrm{W}$ is wet bulb and D is dry bulb temperature in ${ }^{\circ} \mathrm{C}$. Also, rectal temperature $\left(\mathrm{C}^{0}\right)$ and respiration rate (resp./min) were recorded twice daily at mornings and afternoons. Daily milk yields (kg) were recorded each season and reproductive data including number of service per conception (NSPC) and days open were also recorded. Conception rate to first insemination (CR/TAI1), overall pregnancy rate (PR) were calculated. $\mathrm{CR} / \mathrm{AI}=$ proportion of cows pregnant divided by the number of cows inseminated; $\mathrm{PR}=$ proportion of cows pregnant divided by the number of cows enrolled in the study; and days open = interval between calving and confirmed pregnancy dates.

\section{Statistical Analysis}

Conception rates and pregnancy rates were measured at the end of season and were analyzed by Chi Square procedure. However, number of services per conception, days open, daily milk yield, progesterone concentrations and serum biochemical parameters were analyzed using analysis of variance according to GLM procedure (SAS, 2001) to study the effect of the treatment on all traits and parameters studied. The following model was used:

$$
\mathrm{Y}_{\mathrm{ijk}}=\mu+\mathrm{S}_{\mathrm{i}}+\mathrm{T}_{\mathrm{j}}+\mathrm{S}_{\mathrm{i}} \mathrm{T}_{\mathrm{j}}+\mathrm{e}_{\mathrm{ijk}}
$$

Where; $Y_{i j}=$ an observation of each trait studied, $\mu=$ the overall mean of the trait, $S_{i}=$ the effect of $i^{\text {th }}$ season, $T_{j}=$ the effect of $j^{\text {th }}$ time, $S_{i} T_{j}=$ the interaction effect between $i^{\text {th }}$ season and $\mathrm{j}^{\text {th }}$ time and $\mathrm{e}_{\mathrm{ij}}=$ the residual.

\section{Results and Discussion}

It is clearly evident from figure 1 that temperature humidity index (THI) values were greater in summer than winter season (Figure 1) and so were the values for rectal temperature and respiration rates in Holstein 
dairy cows. During the summer season THI ranged from 91 to 96.7 units but in winter season it ranged from 70.3 to 83.4 units. After 45 days in summer, the cows were more sensitive to heat stress as they recorded the highest rectal temperature $\left(39.9{ }^{\circ} \mathrm{C}\right)$ and respiration rate (75.9 resp. /min). Also, changes in rectal temperatures and respiration rates of Holstein dairy cows in winter season were less apparent but it fluctuated in summer season especially the respiration rate which is considered one of the most important means for heat stress alleviation by dairy cows.

The combined effects of temperature and humidity were characterized using the temperature-humidity index (Igono, et al., 1992; Ravagnolo and Misztal, 2000). Ravagnolo, et al. (2000) defined THI $=72$ as the threshold above which milk, fat, and protein yields started to decrease. Spiers et al. (2004) observed an increase in the respiration rate and rectal temperature 1 day after exposure to hot conditions. Characteristic signs of heat stress in dairy cows include an increased rectal temperature and respiratory rate and decreased feed intake (Ingraham et al., 1975; Fuquay, 1981).
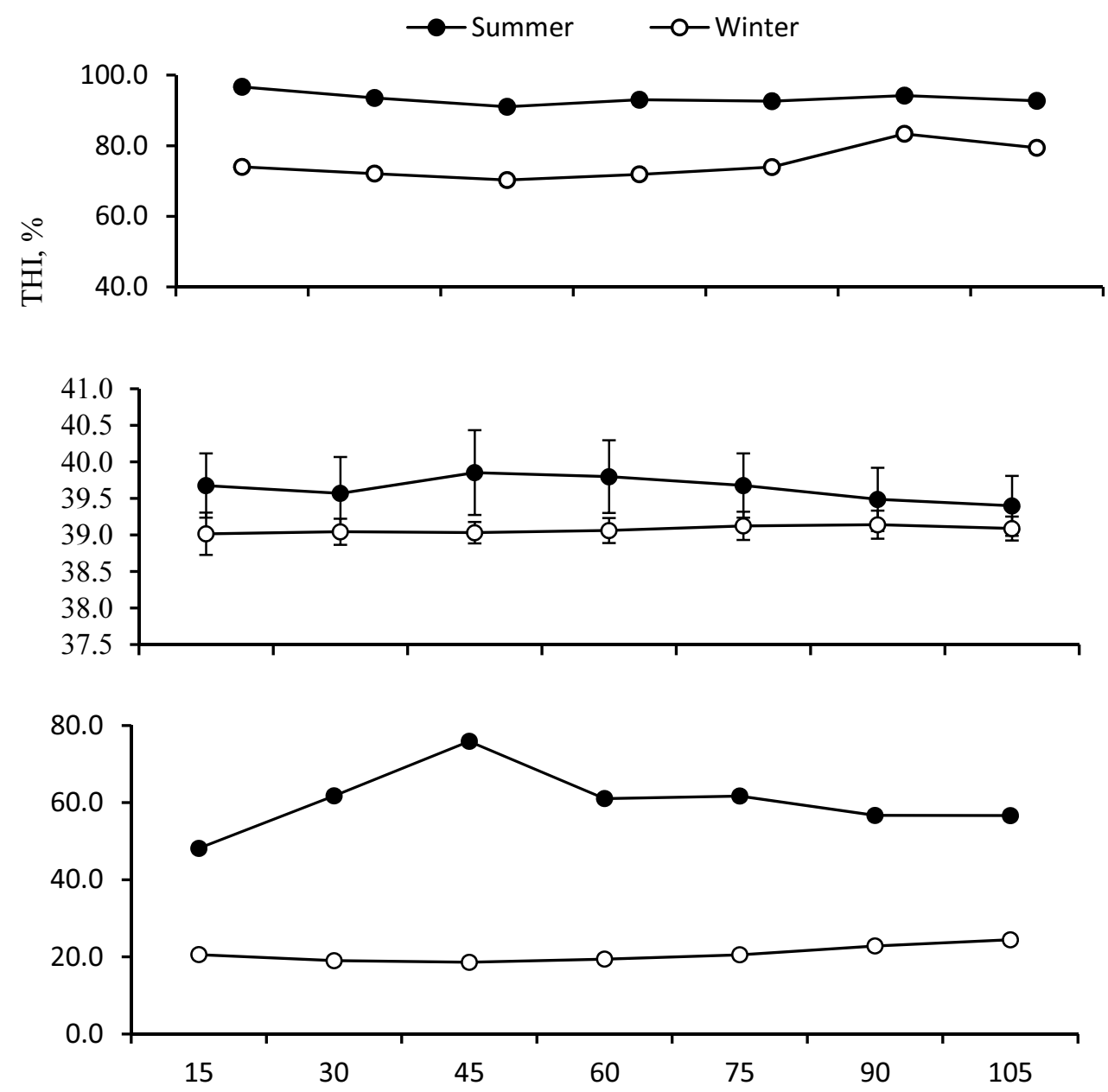

Fig. 1. Changes in THI, rectal temperature, respiration rate in Holstein dairy cows recorded every 15 days during summer and winter seasons. 
Figure 2 illustrated the changes in daily milk yield $(\mathrm{kg})$ for Holstein dairy cows during months of summer and winter seasons. We observed that the daily milk yields were higher in winter than summer along the first four months and thus in the fifth months the daily milk yield nearly became the same. These results may be due to the moderate weather in winter in Egypt which became similar to that for the foreign cows (Holstein) original environment. Also, the summer in subtropical countries causes heat stress on dairy cows especially that originated from colder climates like Holstein cows. So, cows produced more milk in winter than summer. This decrease in milk yield of heatstressed cows may be explained mainly by lower dry matter intake (DMI) and a lower conversion efficiency of feed into milk as reported by Bouraoui, et al. (2002).

With respect to heat stress effects on milk production, it was widely shown in previous research studies that the climatic conditions were more highly correlated with milk yield and composition than the average conditions of other periods preceding the sampling (West, 2003; Bouraoui, et al., 2002). Under the Mediterranean climate, Bouraoui, et al. (2002) reported a decrease in milk yield of $21 \%$ when the THI increased from 68 to 78 . Bernabucci, et al. (2010) studied the effect of heat stress over 2 yr under field conditions and calculated a decrease of $0.27 \mathrm{~kg}$ milk per day for each THI unit increase above 68.

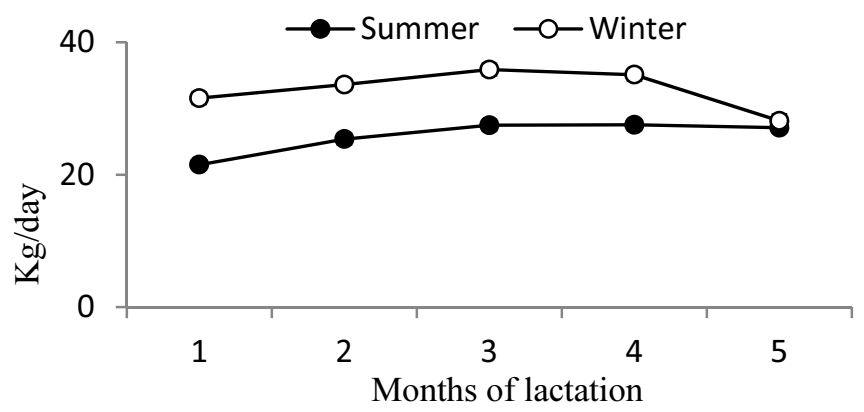

Fig. 2. Changes in average daily milk yield ( $\mathrm{kg} / \mathrm{day})$ for Holstein dairy cows during 5 months of summer and winter seasons.
Table 1 summarized the conception rate to first AI (CR/All), overall pregnancy rate (PR), number of services per conception (NSPC) and days open in Holstein dairy cows during the summer and winter seasons.

Heat stress conditions during summer season did not markedly affect the conception rates to first AI after the application of the Ovsynch protocol (Table 1) despite the presence of some differences in the favor of winter season 23.2 vs. $17.5 \%$. During summer season cows needed more $(\mathrm{P}<0.05)$ services per conception (3.19) compared to cows during winter season (2.47). Similar trend was recorded for the number of days open in summer (179 days) compared to winter (104 days). Due to elevated summer ambient temperature and THI the reproductive performance of the cows was negatively affected in the form of decreased CR/AI and more NSPC and more days open. Heat stress in warm environments is one of the major factors that can negatively affect reproduction, and the health of dairy cows (Jordan, 2003; Bernabucci et al., 2010). López-Gatius (2003) reported that heat stress is attributable to an increase of some reproductive diseases, such as ovarian cysts. Dairy cows with high productive performance are more sensitive to environmental effects (Kadzere et al., 2002) and heat stress causes a decrease of cyclicity and increases the incidence of inactive ovaries (López-Gatius, 2003).

Table 1. Conception rate to first AI (CR/AI, \%), overall pregnancy rate $(\mathrm{PR}, \%)$, number of services per conception (NSPC) and days open in Holstein dairy cows during the summer and winter seasons

\begin{tabular}{lccccc}
\hline \multirow{2}{*}{ Seasons } & & \multicolumn{5}{c}{ parameters } \\
\cline { 3 - 6 } & & CR/AI1 & Overall PR & NSPC & Days Open \\
\cline { 3 - 6 } Summer & & 17.5 & 78 & $3.19^{\mathrm{a}}$ & $179.64^{\mathrm{a}}$ \\
Winter & & 23.33 & 75 & $2.47^{\mathrm{b}}$ & $104.02^{\mathrm{b}}$ \\
\hline
\end{tabular}

${ }^{a-b}$ Values with different letters in the same column $\operatorname{differ}(\mathrm{P}<0.05)$ 
Changes in serum progesterone $(\mathrm{ng} / \mathrm{ml})$ concentrations in Holstein dairy cows at the GnRH and PGF injection times in summer and winter season are presented at Figure 3. During summer season serum P4 concentrations were not altered and did not reflect the physiological status of the cows. This was indicative of no response to the GnRH and probably less new luteal structure were formed and hence no further increase in P4 levels at the PGF injection time after days. But in winter season, serum $\mathrm{P} 4$ concentrations increased after the $\mathrm{GnRH}$ injection as this was considered as an indication of formation of new functional luteal structures. Seasonal studies report lower steroid concentrations in the follicular fluid obtained from large follicles during the hot season associated with reduced viability of granulosa cells (Badinga et al., 1993; Wolfenson et al., 1995). In a study by Wolfenson et al. (1997), androstenedione production by thecal cells was reduced, and low estradiol concentrations were observed in follicular fluid collected from dominant follicles during autumn. Wolfenson et al. (2000) concluded that chronic heat stress reduces progesterone concentrations; however, progesterone concentrations may be increased after an acute heat stress. The mechanisms by which heat stress alters the concentrations of circulating reproductive hormones are not known. Increased corticosteroid secretion has been suggested (Lo'pez-Gatius et al., 2005) because this can inhibit GnRH and thus LH secretion (Johnson et al., 1962).

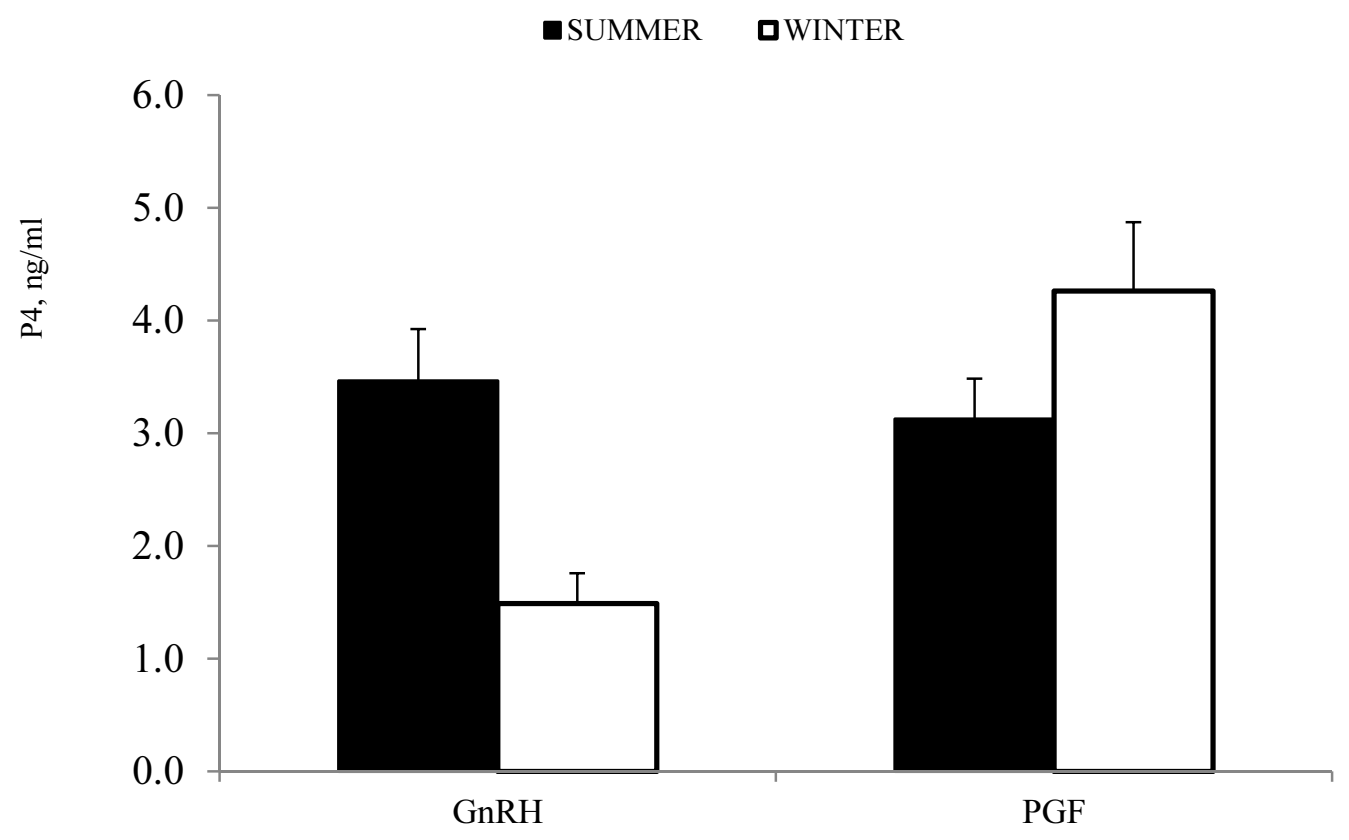

Fig. 3. Changes in serum progesterone (ng/ml) concentrations in Holstein dairy cows at the GnRH and PGF injection times

Changes in serum cholesterol, glucose and urea concentrations in Holstein dairy cows during the dry period, GnRH and PGF injection times are presented in Figure 4. Cholesterol and urea increased from dry to $\mathrm{GnRH}$ injection and then remained altered till the PGF injection in both seasons. Also, it was evident that the concentrations of cholesterol and urea were similar at each point under study (dry period, GnRH and PGF injection times) in summer and winter seasons. However, serum urea concentrations were 
declined in winter season at the PGF injection times compared to summer season. An opposite trend was recorded for cholesterol concentrations. In contrast, serum glucose concentrations were significantly higher in summer than winter at all studied points. Rhoads et al. (2009) and Wheelock et al. (2010) reported an increased concentration of urea during exposure to heat stress with significantly higher concentration in obese cows. Increased urea concentrations around times of insemination and early embryonic development can be harmful to embryonic development as elevated urea concentrations are associated with direct embryonic toxicity. Increased serum cholesterol concentration around times of insemination is a positive physiological response by the cow as cholesterol is the precursor for major steroid hormones synthesis.
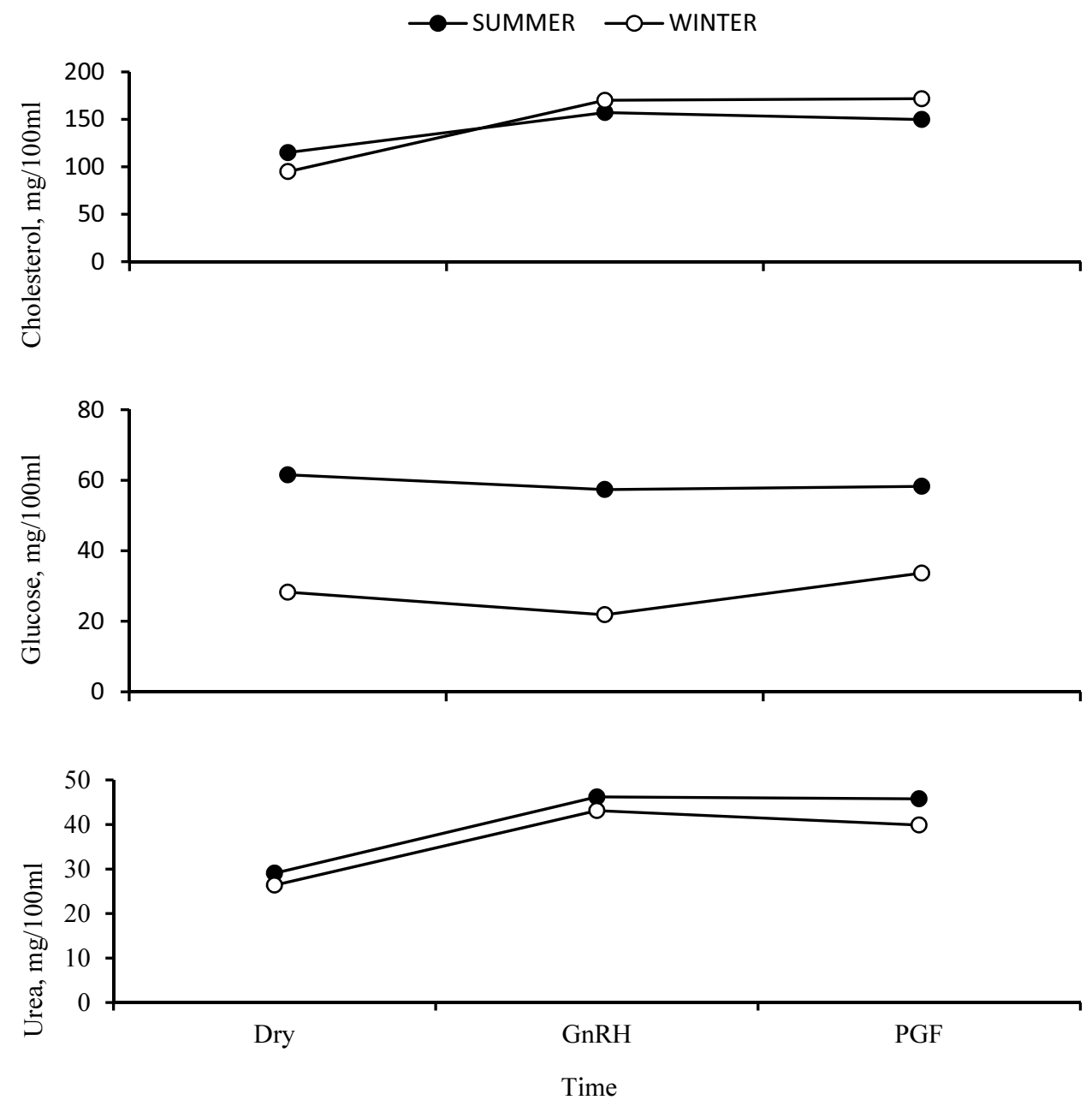

Fig. 4. Changes in serum cholesterol, glucose and urea concentrations in Holstein dairy cows during the dry period, GnRH and PGF injection times.

\section{Conclusion}

Heat stress decreases production and fertility in dairy cows. The decrease in fertility is caused by elevated body temperature that influences ovarian function, estrous expression, oocyte health, and embryonic development. In response to these limitations, dairymen should improve environmental and reproductive management of cows during heat 
stress. For example cooling dairy cows and increasing the frequency of estrous detection will increase pregnancy rates. Timed AI (Ovsynch) may also be used as an alternative to estrous detection.

\section{References}

Badinga, L., Thatcher, W. W., Diaz, T., Drost, M. and Wolfenson, D. (1993) Effect of environmental heat stress on follicular development and steroidogenesis in lactating Holstein cows, Theriogenology, 39: 797-810.

Berman, A. (2005) Estimates of heat stress relief needs for Holstein dairy cows, J. Anim. Sci., 83: 1377-1384.

Bernabucci, U., Lacetera, N. L., Baumgard, H., Rhoads, R. P., Ronchi, B. and Nardone, A. (2010) Metabolic and hormonal acclimation to heat stress in domesticated ruminants, Anim., 4: 1167-1183.

Bouraoui, R., Lahmar, M., Majdoub, A., Djemali, M. and Belyea, R. (2002) The relationship of temperaturehumidity index with milk production of dairy cows in a Mediterranean climate, Anim. Res., 51: 479-491.

Brügemann, K., Gernand, E., König von Borstel, U. and König, S. (2012) Defining and evaluating heat stress thresholds in different dairy cow production systems, Arch. Tierzucht., 55: 13-24.

Collier, R. J., Dahl, G. E. and VanBaale, M. J. (2006) Major advances associated with environmental effects on dairy cattle, J. Dairy Sci., 89: 1244-1253.

Dikmen, S. and Hansen, P. J. (2009) Is the temperaturehumidity index the best indicator of heat stress in lactating dairy cows in a subtropical environment?, J. Dairy Sci., 92: $109-116$.

Fuquay, J. W. (1981) Heat stress as it affects animal production, J. Anim. Sci., 52: 164-174.

Gauly, M., Bollwein, H., Breves, G., Brügemann, K., Dänicke, S., Daú, G., Demeler, J., Hansen, H., Isselstein, J., König, S., Lohölter, M., Martinsohn, M., Meyer, U., Potthoff, M., Sanker, C., Schröder, B., Wrage, N., Meibaum, B., von Samson-Himmelstjerna, G., Stinshoff, H. and Wrenzycki, C. (2013) Future consequences and challenges for dairy cow production systems arising from climate change in Central Europe-A review, Anim., 7: 843-859.

Hahn, G. L., Mader, T. L. and Eigenberg, R. A. (2003) Perspective on development of thermal indices for animal studies and management, EAAP Technic. Ser., 7: 31-44.

Hansen, P. J. and Arechiga, C. F. (1999) Strategies for managing reproduction in the heat-stressed dairy cow, $J$. Anim Sci., 77, 36-50.

Hubbard, K. G., Stooksbury, D. E., Hahn, G. L. and Mader, T. L. (1999) A climatologic perspective on feedlot cattle performance and mortality related to the temperature-humidity index. J. Prod. Agric., 12, 650-653.

Igono, M. O., Bjotvedt, G. and Sanford-Crane, H. T. (1992) Environmental profile and critical temperature effects on milk production of Holstein cows in desert climate, Int. $J$. Biometeorol., 36: 77-87.
Ingraham, R. H., Stanley, R. W. and Wagner, W. C. (1975) Relationship of temperature and humidity to conception rate of Holstein cows in Hawaii, J. Dairy Sci., 59: 20862090.

Ispierto, G. I., Gatius, F. L., Sabat, B. G., Santolaria, P., Yaniz, J. L., Nogareda, C., De Rensis, F. and Bejar, L. M. (2007) Climate factors affecting conception rate of high producing dairy cows in northeastern Spain, Theriogenology, 67: 1379-1385.

Johnson, H. D., Ragsdale, A. C., Berry, I. L. and Shanklin, M. D. (1962) Effect of various temperature-humidity combinations on milk production of Holstein cattle, $M$. Agric. Exp. Stn. Res. Bull., 791: 1-39.

Jordan, E. R. (2003) Effects of heat stress on reproduction, J. Dairy Sci., 86: 104-114.

Kadokawa, H., Sakatani, M. and Hansen, P. (2012) Perspectives on improvement of reproduction in cattle during heat stress in a future Japan, Anim. Sci. J., 83: 439445 .

Kadzere, C. T., Murphy, M. R., Silanikove, N. and Maltz, E. (2002) Heat stress in lactating dairy cows: A review, Livest. Prod. Sci., 77: 59-91.

López-Gatius, F. (2003) Is fertility declining in dairy cattle? A retrospective study in northeastern Spain, Theriogenology, 60: 89-99.

López-Gatius, F., López-Béjar, M., Fenech, M. and Hunter, R. H. F. (2005) Ovulation failure and double ovulation in dairy cattle: risk factors and effects, Theriogenology, 63: 1298-1307.

NRC, National Research Council, (2007) Nutrient Requirements of dairy cattle, National Academy Press, Washington, DC.

Ravagnolo, O. and Misztal, I. (2000) Genetic component of heat stress in dairy cattle, parameter estimation, J. Dairy Sci., 83: 2126-2130.

Ravagnolo, O., Misztal, I. and Hoogenboom, G. (2000) Genetic component of heat stress in dairy cattle, development of heat index function, J. Dairy Sci., 83: 2120-2125.

Rhoads, M. L., Rhoads, R. P., VanBaale, M. J., Collier, R. J., Sanders, S. R., Weber, W. J., Crooker, B. A. and Baumgard, L. H. (2009) Effects of heat stress and plane of nutrition on lactating Holstein cows: I. Production, metabolism, and aspects of circulating somatotropin, $J$. Dairy Sci., 92: 1986-1997.

SAS, Statistical Analysis Systems (SAS) Institute (2001) Version 8. SAS Institute, Cary, NC, USA.

Spiers, D. E., Spain, J. N., Sampson, J. D. and Rhoads, R. P. (2004) Use of physiological parameters to predict milk yield and feed intake in heat-stressed dairy cows, $J$. Therm. Biol., 29: 759-764.

West, J. W. (2003) Effects of heat-stress on production in dairy cattle, J. Dairy Sci., 86: 2131-2144.

Wheelock, J. B., Rhoads, R. P., VanBaale, M. J., Sanders, S. R. and Baumgard, L. H. (2010) Effects of heat stress on energetic metabolism in lactating Holstein cows, $J$. Dairy Sci., 93: 644-655. 
Wolfenson, D., Lew, B. J., Thatcher, W. W., Graber, Y. and Meidan, R. (1997) Seasonal and acute heat stress effects on steroid production by dominant follicles in cow, Anim. Reprod. Sci., 47: 9-19.

Wolfenson, D., Roth, Z. and Meidan, R. (2000) Impaired reproduction in heat stressed cattle: basic and applied aspects, Anim. Reprod. Sci., 60: 535-547.

Wolfenson, D., Thatcher, W., Badinga, L., Savio, J., Meidan, R., Lew, B., Braw-Tal, R. and Berman, A.
(1995) The effect of heat stress on follicular development during the estrous cycle in lactating dairy cattle, Biol. Reprod., 52: 1106-1113.

Yousef, M. K. (1987) Principles of bioclimatology and adaptation. Pages 17-31 in Bioclimatology and the Adaptation of Livestock. World Animal Science, Subseries B: Disciplinary Approach, 5. H. D. Johnson, ed. Elsevier Science Publishers B.V., Amsterdam, the Netherlands. 
التغيرات المناخية في الأداء الإنتاجي والتتاسلي لأبقار الهولستين الحلابة المعاملة بيرنامج الـ Ovsynch في الظروف تحت الاستوائية

محمد محمد شعبان' وعمرو محمد رشاد' وأحمد الطاهر مهاى' وسمير زكى الزرقوني ', وجمال الدين

'قسم الإنتاج الحيواني والسدكي، كلية الزراعة، جامعة الإسكندرية، جهورية مصر العربية

"اتقم زراعة الدناطق الجافة، كلبة الأرصاد والبيئة وزراعة الدناطق الجافة، جامعة العلك عبدالعزبز، جدة، المدلكة العربية السعودية

الدستخلص. هذه الدراسة هدفت إلى تقييم تأثيرات الإجهاد الحراري على الأداء الإنتاجي والتتاسلي لأبقار

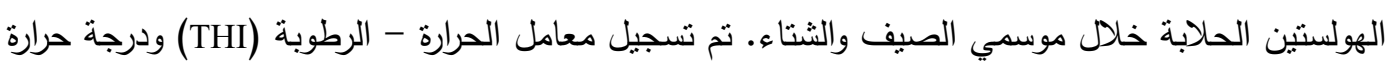

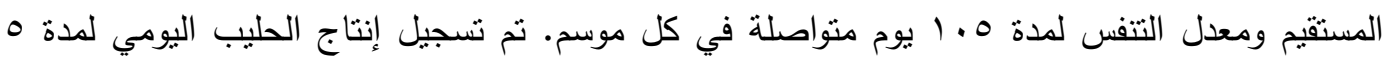

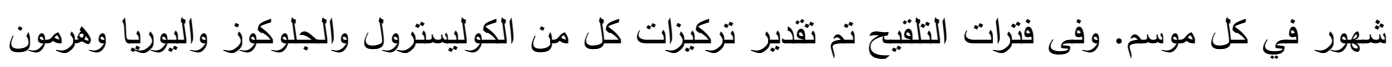

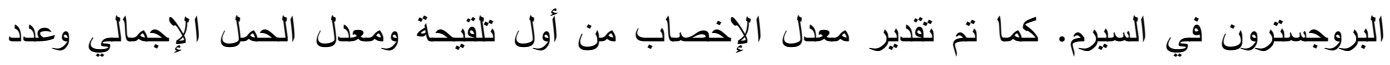

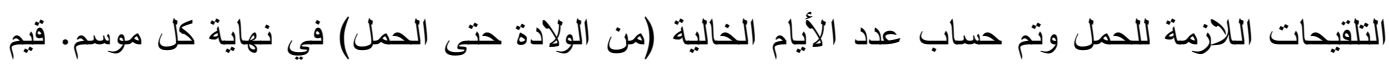

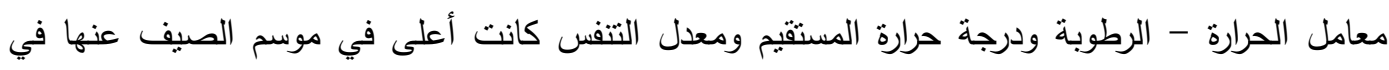

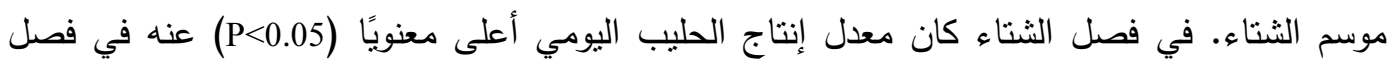

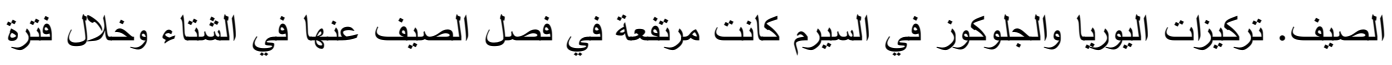

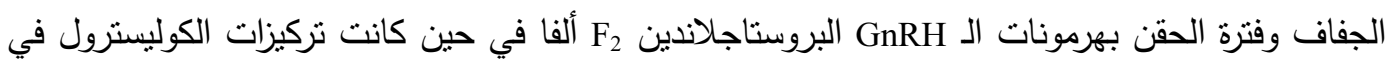

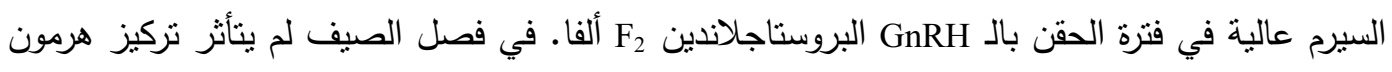

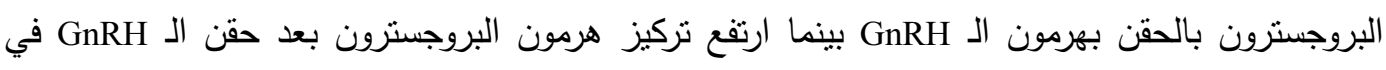

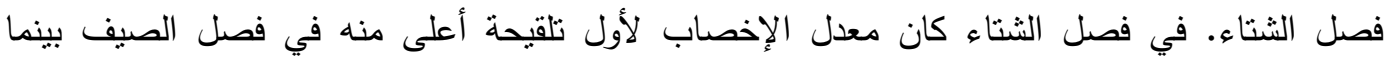

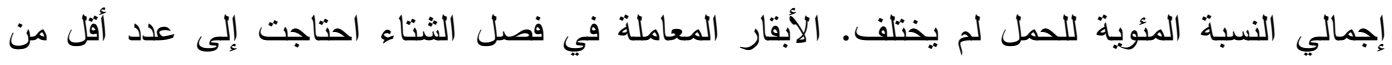

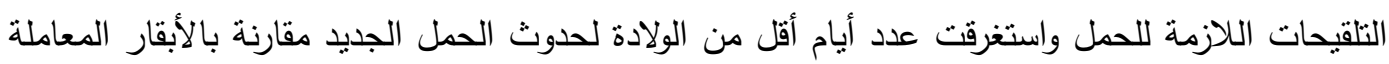
في فصل الصيف. الكلمات الدالة: موسم، إجهاد حرارى، حليب، بقرة، خصوبة. 